\title{
Research on Installation Technologies of Retaining Walls with Ground Anchors
}

\section{Mindaugas Žagarinskas}

UAB “Projektana”, Chemijos str. 23D, LT-51331 Kaunas, Lithuania

\section{Mindaugas Daukšys*, Jūratė Mockienė}

Kaunas University of Technology, Faculty of Civil Engineering and Architecture, Studentu st. 48, LT-51367 Kaunas, Lithuania

*Corresponding author: mindaugas.dauksys@ktu.lt

Гrossef http://dx.doi.org/10.5755/j01.sace.26.1.21540,

With increasing level of urbanization, new buildings are erected in close proximity to existing buildings or quite close to site boundaries. Such practice affects the complexity of retaining wall installation technology. When a retaining wall is installed close to an existing building, a street or a steep slope, the stability of the wall has to be ensured first. There are cases when a retaining wall has to be strengthened by creating a permanent or temporary support, i.e. by installing ground anchors. According to literature analysis, the major problem is that a profile stops without reaching its designed depth (Van Baars). Merifield et al. distinguish three major types of anchors: circular, square and rectangular. They emphasise that anchor surface unevenness does not impact anchor resistance. According to Nagar, most frequently anchors disintegrate due to excessive tensile strength of the anchor. The increase of this force is related to tensile strength measured in anchor testing. In this paper, three types of retaining walls with ground anchors are considered: pile wall, Berlin Wall, and sheet piling with excavation depth of $6 \mathrm{~m}$. The conditions are selected as follow: when walls are installed in clay soils, sandy soils, sandy soils at high groundwater levels, and when the wall is installed next to the building. Mechanical resistance and stability of construction incline are calculated by means of GE05 software. A survey was designed basing on the calculation results and the selected evaluation criteria. In the survey geotechnical engineers rated 18 different cases. The relevance of criteria is determined by employing the entropy method after the primary results of the survey are summarised; afterwards a multiple criteria decision analysis carried out using the utility function. The multi-criteria assessment results indicate the most rational type of a retaining wall for the chosen conditions. This article is based on master thesis topic "Research on Installation Technologies of Retaining Walls with Ground Anchors".

Keywords: ground anchors, retaining wall, entropy method, multi-criteria assessment,survey research.

Ordinary retaining walls are seldom used nowadays. Increasing urban density levels lead to the construction of new buildings next to the existing foundation or very close to the site boundaries. Such trends of urban planning influence the complexity of retaining wall construction. When a retaining wall is installed close to an existing building, a street or a steep slope, the stability of the wall has to be ensured first. Supporting walls from the ground surface are erected to provide the required stability. There are cases when a retaining wall has to be strengthened by creating a permanent or temporary support, i.e. by installing ground anchors.

The selection of the retaining wall type and its strength depends on the existing geological condi-

\section{Introduction}

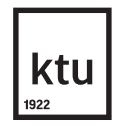

Journal of Sustainable Architecture and Civil Engineering Vol. 1 / No. 26 / 2020

pp. 53-64

DOI 10.5755/j01.sace.26.1.21540 
tions. It might be difficult to drive or hammer elements into hard or dense soils.

Sheet pile walls are most often used to retain the movement of water or soil. Sheet piling technology is described in AARSLEFF 2016a. The capacity of the sheet pile to withstand different forces depends not only on the soil into which the sheet pile is driven but also on the characteristics of the element's cross-section. Sheet pile walls may have the length of 31 meter or even up to 33 meters in the case of H-type walls(Katkevicius and Baublys 2008).

Byfield and Mawer (2004) argue that interlocked sheet piles form a solid wall. U-elements have locks on the neutral axis, which corresponds with the maximum shear stress; therefore, the joints must be welded to increase the wall's retaining strength. Welded joints increase the resistance to the bending moment up to three times compared to the load bearing strength of a single element. The locks are filled with various synthetic waterproofing materials to ensure the waterproofing capacity of the retaining wall.

First of all, the behaviour of steel in different corrosive environments must be examined in order to extend the service life of the wall with appropriately selected cross-section and required protective measures. In practice, two sides of the steel wall are often exposed to different media and thus detailed studies are necessary to ensure the maximum protection (AMPH 2008).

Researcher R.W. investigated into the effect of ground water on the retaining wall in different cases: at the same water level on both sides of the wall and at a lower water level on one side of the wall.

Different water levels and their effect on the retaining wall must be examined for marine structures. The part of the wall, which is closer to the sea bottom, is exposed to corrosion the least, approx. $0.012 \mathrm{~mm}$ per year. No severe corrosion occurs in the permanent submersion level either, where the wall is exposed to clean water with the surface of the water covered by a layer of marine flora. The most severe corrosion occurs in tide water conditions or on the surface water level due to a frequent change of corrosive factors (Kreišmantas 2016).

Van Baars (2004) argues that in cases when sheet piles are driven by using vibratory technique, the conditions of the soil must be carefully examined in order to select the vibratory hammer with appropriate characteristics. Vibratory hammers can be used only for driving sheet piles in weak soils, i.e. soft clays, silt or peat, also in sand permeated with water and hawing a low modulus of elasticity. Different problems occur when sheet piling is installed by means of vibratory techniques. Van Baars (2004) highlights a problem when the pile ceases penetrating the soil before the design depth is reached. The article discusses three main equations, one taken from CUR, another from EAU, and the third equation is proposed by the author basing on the Vibdrive modelling results. CUR are Dutch compliance standards. This method lacks one very important factor, namely the ground conditions.

Supporting walls are complex and expensive structures and the engineers designing them must have good knowledge in geotechnical engineering. Dedicated computer programmes are used to design these structures. These computer programmes are usedto assess all conditions and select the most rational alternative of the structure within the estimated cost of materials.

The required amount of reinforcing bars is one of the key characteristics. The amount of reinforcing bars in retaining walls is usually big and even very big because the structure must bear the ground load, big transverse loads and bending moment caused by other factors. However, the poles of the retaining wall are affected only from one side. Therefore, the strain in the cross section is always the same. It means that the strained and compressed zone does not change its position. Reinforcement tendons are required to resist the tensile stress and there is no need to use reinforcement tendons of big cross section on the side where it is not necessary. Reinforcement tendon installation technology is described in AARSLEFF 2016.

Gil-Martin et al. (2010) review the optimisation of pile wall reinforcement. The authors argue that the flexural strength of the pile's cross-section increases when the reinforcement of the tension 
zone is strengthened, and reinforcement of the compressed zone remains unchanged. This is evidenced by iteration diagrams. The flexural strength of the cross-section increases significantly when the number of reinforcement tendons is increased from 1 to 10.

The ground anchor is composed of pre-stressed steel tendon and injected cementitious mortar. The anchor transfers the loads to the ground through the friction between the anchor and the surrounding soil. The injected cementitious mortar provides the support to the tensioned steel tendon. Merifiels et al (2003) distinguished three types of anchors: round, square and rectangular. The authors note that the roughness of round, square and rectangular anchors has no significant effect on anchor's resistance.

The analysis of reasons for anchor damage reveals several major conditions leading to anchor damage. According to Nagar (2010), the most common reason for anchor failure is the excessive tensile force. The increase of this force is related to tensile strains applied in pre-tensioning. It is important to test not only the maximum load that the anchor can bear but also the load that causes the cracking of fine-grained concrete. Concrete cracking leads to the corrosion of the steel tendon.

Steel tendons in permanent anchors must be protected from corrosion by the coat of anti-corrosive material, which must remain intact throughout the designed service life of the anchor. Alternatively, anchor tendons may have two protective barriers. Resins can be used as one of the permanent anti-corrosive barriers, provided they are intact, protected and not over-pressed. The resin can be injected or coated in $5 \mathrm{~mm}$ layer during the pretensioning (LST EN 1537).

If the design provides that the load from retaining walls will be transferred to other structures, installation of permanent anchors is not required because the load will be transferred to constructed floors. In such cases temporary anchors are installed and cut off after the floor is constructed. In many cases such a solution saves retaining wall building costs (Konstantakos 2010).

The aim of this work is to evaluate the effect of existing geological soil conditions on retaining wall installation technologies with temporary ground anchors.

Several variants of geological soil conditions of the were selected for the evaluation of retaining walls with ground anchors. The first variant was sticky clay soil and the second variant was granular sandy soil with a high level of ground water. Geological cross-section diagrams were used for the computation. Parameters of sticky clay soil and granular sandy soil are presented in Table 1, 2.

\begin{tabular}{|c|c|c|c|c|}
\hline Parameters & $\begin{array}{l}\text { Poured } \\
\text { soil }\end{array}$ & $\begin{array}{l}\text { Striped clay, } \\
\text { hard plastic }\end{array}$ & $\begin{array}{l}\text { Sandy, clayey } \\
\text { moraine dust }\end{array}$ & $\begin{array}{l}\text { Sandy, clayey } \\
\text { moraine dust, hard }\end{array}$ \\
\hline Unit weight, $\mathrm{kN} / \mathrm{m}^{3}$ & 18.00 & 18.10 & 19.90 & 22.10 \\
\hline Stress-state & effective & effective & effective & effective \\
\hline Angle of internal friction, ${ }^{\circ}$ & 25.00 & 11.00 & 24.00 & 35.00 \\
\hline Cohesion of soil, $\mathrm{kPa}$ & 0.00 & 32.00 & 13.00 & 63.00 \\
\hline Angle of friction struc.-soil, ${ }^{\circ}$ & 17.00 & 7.00 & 16.00 & 17.00 \\
\hline Soil & cohesionless & cohesive & cohesive & cohesive \\
\hline Poisson's ratio & 0.35 & 0.35 & 0.35 & 0.35 \\
\hline Deformation modulus, MPa & 5.00 & 9.00 & 18.00 & 325.00 \\
\hline Saturated unit weight, $\mathrm{kN} / \mathrm{m}^{3}$ & 20.00 & 18.50 & 20.50 & 22.50 \\
\hline Pattern & 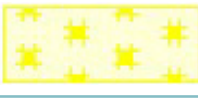 & + & & \\
\hline Marking in computation scheme & $1(4)$ & 2 & 3 & 5 \\
\hline
\end{tabular}

Table 1

Parameters of sticky clay soil 


\begin{tabular}{|c|c|c|c|c|c|c|}
\hline \multirow{12}{*}{$\begin{array}{l}\text { Parameters } \\
\text { of granular } \\
\text { sandy soil }\end{array}$} & Parameters & $\begin{array}{c}\text { Primer } \\
\text { soil }\end{array}$ & $\begin{array}{l}\text { Gravel } \\
\text { sand }\end{array}$ & $\begin{array}{l}\text { Gravel } \\
\text { sand } 12\end{array}$ & Fine sand & $\begin{array}{l}\text { Medium } \\
\text { rough sand }\end{array}$ \\
\hline & Unit weight, $\mathrm{kN} / \mathrm{m}^{3}$ & 18.00 & 19.10 & 19.30 & 17.00 & 17.20 \\
\hline & Stress-state & effective & effective & effective & effective & effective \\
\hline & Angle of internal friction, ${ }^{\circ}$ & 25.00 & 41.00 & 44.00 & 43.00 & 42.00 \\
\hline & Cohesion of soil, kPa & 0.00 & 0.00 & 0.00 & 0.00 & 0.00 \\
\hline & $\begin{array}{l}\text { Angle of friction struc.-soil, } \\
\text { oand compressed. }\end{array}$ & 16.00 & 17.00 & 17.00 & 17.00 & 17.00 \\
\hline & Soil & cohesionless & cohesionless & cohesionless & cohesionless & cohesionless \\
\hline & Poisson's ratio & 0.35 & 0.35 & 0.35 & 0.35 & 0.35 \\
\hline & Deformation modulus, MPa & 3.50 & 53.30 & 79.00 & 85.60 & 80.60 \\
\hline & Saturated unit weight, $\mathrm{kN} / \mathrm{m}^{3}$ & 20.00 & 21.00 & 21.00 & 19.00 & 19.00 \\
\hline & Pattern & & $\begin{array}{|lll|} & 0 & 0 \\
b & \wedge & 0\end{array}$ & & $\circ \circ$ & $\circ \quad \circ$ \\
\hline & $\begin{array}{l}\text { Marking in computation } \\
\text { scheme }\end{array}$ & 1 & 2 & $3(5)$ & $4(7)$ & $6(8)(9)$ \\
\hline
\end{tabular}

Investigation conditions: retaining wall with temporary ground anchors driven to 6-meter depth from the top, the load received from the existing building is $200 \mathrm{kN} / \mathrm{m}^{2}$, the foundation of the existing building is 1 meter wide, the distance between the central axis of the foundation and the retaining wall is $1.5 \mathrm{~m}$. Wall footing was chosen as a foundation type for the research.

Temporary ground anchors are necessary to take over a huge tensile strength to supporting base layers for a limited period of time ( $<2$ years). A temporary ground anchor consists of an injected stem, a stringer with a free part and an anchor. External boring diameter of temporary ground anchors is $133 \mathrm{~mm}$. Anchors are bored by a spiral drill in protective tubes with air blow. When a hole is made cement mortar is poured, later a stringer is installed. Anchor stem is injected in the ground by mortar which is pressed by high pressure through a distracted protective tube. In 12 hours a following anchor injection is made. After 7 days, the anchor is tested and compressed. Anchors supporting

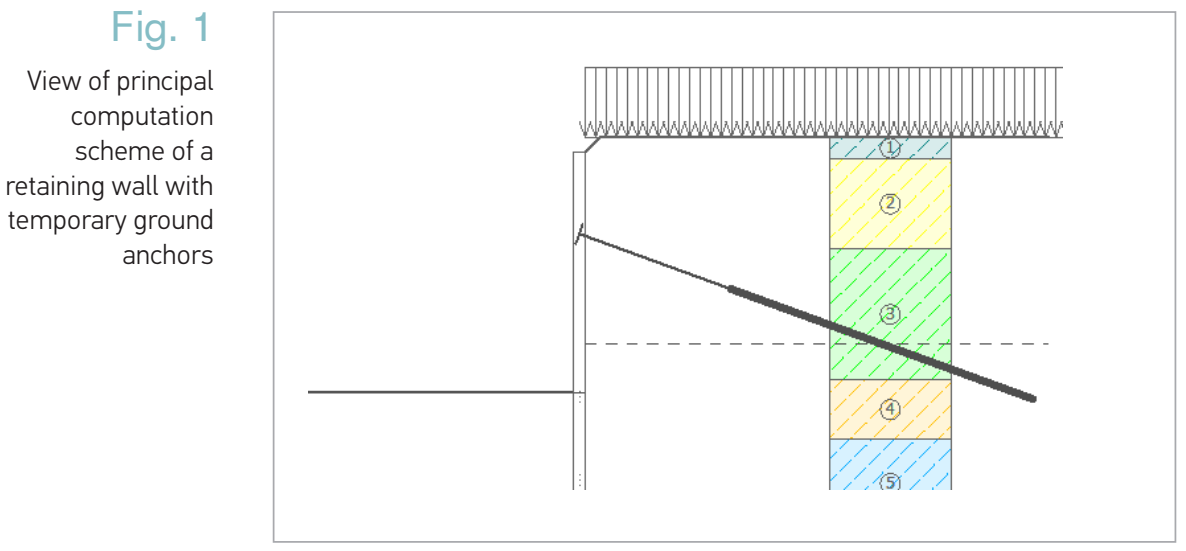
retaining constructions are installed in the same level, usually above water level. If a designer has foreseen to transfer the pressure of retaining walls to other constructions, it means that permanent anchors are not to be installed as the pressure will be transferred to entablatures after their installation. In such a case, temporary ground anchors are installed which are cut off after the entablatures are installed. Such a decision allows to save costs on retaining wall installation (Fig. 1) GEO 5 software was used for the tests. GEO 5 is an effective software package based on analytical and finite element methods and developed for solving geotechnical problems. The obtained results were used in further tests. 
Fig. 1 illustrates principal computation scheme of a retaining wall with temporary ground anchors. Ground layers are marked by numbers according to the geological excavation report (Tables 1, 2). The depth scale is given on the right. The load used in the computation $\left(10 \mathrm{kN} / \mathrm{m}^{2}\right)$ is presented as distributed load on the top of the scheme. The load of the adjacent building (selected as $200 \mathrm{kN} / \mathrm{m}^{2}$ ) borne by the retaining wall is added at the bottom of the foundation. The blue dotted line shows the ground water level, which is different on both sides of the structure. It is the maximum level planned for the service life of the structure. The length and height of the structure shows the maximum excavation depth. The triangle marking in the scheme shows the depth of the ground anchor (Fig. 3).

A survey was conducted according to the developed questionnaire based on specific conditions and criteria used by the interviewees to evaluate each type of the retaining wall in points from 1 to 5 . The questionnaire was given to the staff of the companies constructing retaining walls with ground anchors in Lithuania: UAB Projektana, UAB Vilniaus Rentinys, UAB Geotechnikos grupe II and UAB Pamatu ranga. The following retaining wall construction principles were evaluated by the questionnaire (Table 3).

\section{Case 1 - Retaining walls with ground anchors in sandy soil with a high level of groundwater}

\begin{tabular}{l|l}
\hline Berlin Wall & Steel grade S355 HEB 280 type profiles, length $L=12 \mathrm{~m}$ \\
\hline Pile Wall & $\begin{array}{l}\text { Piles with the diameter of } \varnothing 450 \mathrm{~mm} \text {, length } \mathrm{L}=11 \mathrm{~m} \text {, reinforced with } \\
8 \varnothing 18 \mathrm{~mm} \text { S500 tendons along the entire length, concrete class C25/30 }\end{array}$ \\
\hline Sheet Piles & Steel grade S355 Larsen VL503 tongue, L=10 m \\
\hline
\end{tabular}

Case 2 - Retaining walls with ground anchors installed close to existing buildings in sandy soil with a high level of groundwater

\begin{tabular}{l|l}
\hline Berlin Wall & Steel gradeS355 HEB 340 type profiles, length $L=12 \mathrm{~m}$ \\
\hline Pile Wall & $\begin{array}{l}\text { Piles with the diameter of } \varnothing 450 \mathrm{~mm} \text {, length } L=12 \mathrm{~m} \text {, reinforced with } \\
8 \varnothing 20 \mathrm{~mm} \text { S500 tendons along the entire length, concrete class C25/30 }\end{array}$ \\
\hline Sheet Piles & Steel grade S355 Larsen VL606 tongue, $L=12 \mathrm{~m}$ \\
\hline
\end{tabular}

Case 3 - Retaining walls with ground anchors in sandy soil (without groundwater and a building in close proximity)

\begin{tabular}{l|l}
\hline Berlin Wall & Steel grade S355 HEB 240 type profiles, length $L=10 \mathrm{~m}$ \\
\hline Pile Wall & $\begin{array}{l}\text { Piles with the diameter of } \varnothing 450 \mathrm{~mm} \text {, length } \mathrm{L}=9 \mathrm{~m} \text {, reinforced with 8Ø18 } \\
\mathrm{mm} \text { S500 tendons along the entire length, concrete class C25/30 }\end{array}$ \\
\hline Sheet Piles & Steel grade S355 Larsen VL503 tongue, L=8 m \\
\hline
\end{tabular}

Case 4 - Retaining walls with ground anchors in sandy soil (without water) close to existing buildings)

\begin{tabular}{|c|c|}
\hline Berlin Wall & Steel grade S355 HEB 260 type profiles, length $L=10 \mathrm{~m}$ \\
\hline Pile Wall & $\begin{array}{l}\text { Piles with the diameter of } \varnothing 450 \mathrm{~mm} \text {, length } L=11 \mathrm{~m} \text {, reinforced with } \\
8 \emptyset 25 \mathrm{~mm} \text { S500 tendons along the entire length, concrete class } C 25 / 30\end{array}$ \\
\hline Sheet Piles & Steel grade S355 Larsen VL503 tongue, L=9 m \\
\hline \multicolumn{2}{|c|}{ Case 5 - Retaining walls with ground anchors in clay soil } \\
\hline Berlin Wall & Steel grade S355 HEB 220 type profiles, length L=8 m \\
\hline Pile Wall & $\begin{array}{l}\text { Piles with the diameter of } \varnothing 450 \mathrm{~mm} \text {, length } L=8 \mathrm{~m} \text {, reinforced with } 8 \varnothing 16 \\
\mathrm{~mm} \text { S500 tendons along the entire length, concrete class } C 25 / 30\end{array}$ \\
\hline Sheet Piles & Steel grade S355 Larsen VL503 tongue, L=8 m \\
\hline \multicolumn{2}{|c|}{ Case 6 - Retaining walls with ground anchors in clay soil close to existing building } \\
\hline Berlin Wall & Steel grade S355 HEB 300 type profiles, length L=9 m \\
\hline Pile Wall & $\begin{array}{l}\text { Piles with the diameter of } \varnothing 450 \mathrm{~mm} \text {, length } L=9 \mathrm{~m} \text {, reinforced with } \\
8 \varnothing 18 \mathrm{~mm} \text { S500 tendons along the entire length, concrete class C25/30 }\end{array}$ \\
\hline Sheet Piles & Steel grade S355 Larsen VL503 tongue, L=9 m \\
\hline
\end{tabular}

\section{Table 3}

Initial information for interviewees 
Each case was analysed with the selected types of retaining walls (options). The views of the selected types of retaining walls are given in Figs 2 a-c.

Fig. 2

The views of the selected types of retaining walls (www.aarsleff.com. $\mathrm{pl} / \mathrm{lt})$

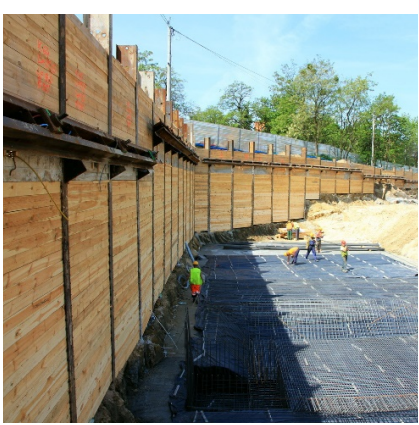

a) A1 - Berlin Wall

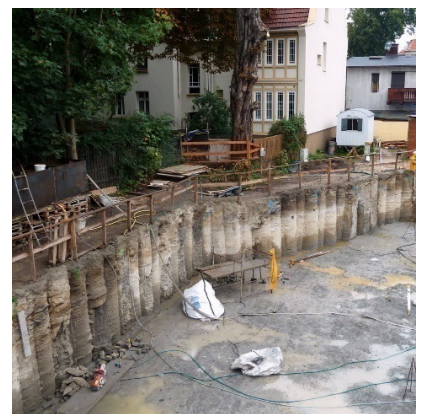

b) A2 - pile wall

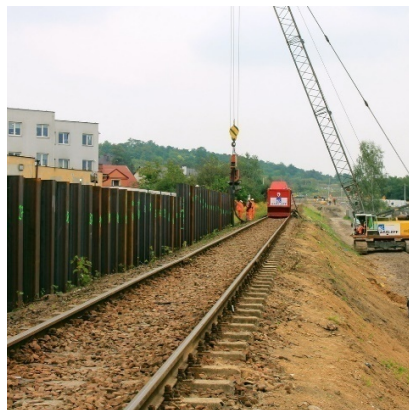

c) A3 - sheet wall

The same types of wall installation and retaining wall options and criteria applied for their evaluation were also used with other evaluation techniques. The options of supporting walls were evaluated in the questionnaire according to the following criteria:

K1 - labour cost, EUR/m, which means the cost of labour to install 1 meter of retaining wall.

- K2 -machinery cost, EUR/m, which means the cost of machinery to install 1 meter of retaining wall.

_ K3 -material cost, EUR/m, which means the cost of materials to install 1 meter of retaining wall.

- K4 - seasonality, scores, which means the influence of the season (spring, summer, autumn, winter), for the selection of retaining wall option.

_ K5 - installation time, scores, which means the time required to install the selected type of retaining wall.

Evaluation criteria: the values of labour cost, EUR/m; machinery cost, EUR/m; cost of materials, $\mathrm{EUR} / \mathrm{m}$ calculated using estimate computation programme. Seasonality in scores was evaluated considering the possibility to install the wall in all seasons and the installation time in scores was calculated considering the complexity of work.

The entropy technique was used to determine the weighting factor of evaluation theoretical and integrated criteria's. The selected values of criteria (K1-K5) that describe the options of selected types of retaining walls are presented in the initial Matrix A of alternative solutions (Table 4).

\section{Table 4}

View of initial Matrix

A of alternative solutions

\begin{tabular}{|c|c|c|c|c|c|}
\hline Options Criteria & $\begin{array}{c}\text { K1, Labour cost, } \\
\text { EUR/m }\end{array}$ & $\begin{array}{l}\text { K2, Machinery } \\
\text { cost, EUR/m }\end{array}$ & $\begin{array}{l}\text { K3, Material } \\
\text { cost, EUR/m }\end{array}$ & $\begin{array}{l}\text { K4, Seasonali- } \\
\text { ty, scores }\end{array}$ & $\begin{array}{l}\mathrm{K} 5 \text {, Installation } \\
\text { time, scores }\end{array}$ \\
\hline Al & $\ldots$ & $\ldots$ & $\ldots$ & $\ldots$ & $\ldots$ \\
\hline $\mathrm{A} 2$ & $\ldots$ & $\ldots$ & $\ldots$ & $\ldots$ & $\ldots$ \\
\hline A3 & $\ldots$ & $\ldots$ & $\ldots$ & $\ldots$ & $\ldots$ \\
\hline Total sum & $\ldots$ & $\ldots$ & $\ldots$ & $\ldots$ & $\ldots$ \\
\hline $\begin{array}{l}\text { Optimization } \\
\text { direction }\end{array}$ & MIN & MIN & MIN & MAX & MAX \\
\hline
\end{tabular}


The initial matrix A was normalised using equation (1):

$$
\overline{P_{i j}}=\frac{x_{i j}}{\sum_{i=1}^{m} x_{i j}} ; \quad\left(V_{i j}, \text { kai } i=\overline{1, m} ; j=\overline{1, n}\right)
$$

Normalization of initial Matrix A produces non-dimensional values $\left(x_{i, j}\right)$.

Entropy order $E_{j}$ is determined for each criterion according to equation (2):

$$
E_{j}=-k \sum_{i=1}^{m}\left(P_{i j} \cdot \ln P_{i j}\right), \quad(i=\overline{1, m}, \quad j=\overline{1, n}), \quad k=\frac{1}{\ln m}
$$

Additional matrix $\left(P_{i j} \cdot \ln P_{i j}\right)$ is created to make the calculation easier.

The criteria change level $d j$ is determined according to equation (3):

$$
d_{j}=1-E_{j}, \quad k u r(j=\overline{1, n})
$$

As all criteria are equally significant, theoretical weight of criteria is found using (4) equation:

$$
q_{j(t)}=\frac{d_{j}}{\sum_{j=1}^{n} d_{j}} ;(j=\overline{1, n})
$$

The integrated weight of criteria is calculated using (5) equation:

$$
\overline{q_{j 0}}=\frac{\overline{q_{j}} \cdot q_{j(t)}}{\sum_{j=1}^{n}\left(\overline{q_{j}} \cdot q_{j(t)}\right)} ; \quad(j=\overline{1, n})
$$

\begin{tabular}{|c|c|c|c|c|c|}
\hline Options Criteria & $\begin{array}{c}\text { K1, } \\
\text { Labour cost, } \\
\text { EUR/m }\end{array}$ & $\begin{array}{c}\text { K2, } \\
\text { Machinery } \\
\text { cost, EUR/m }\end{array}$ & $\begin{array}{c}\mathrm{K} 3, \\
\text { Material cost, } \\
\text { EUR/m }\end{array}$ & $\begin{array}{c}\text { K4, } \\
\text { Seasonality, } \\
\text { scores }\end{array}$ & $\begin{array}{c}\mathrm{K} 5 \\
\text { Installation } \\
\text { time, scores }\end{array}$ \\
\hline A1 & $\ldots$ & $\ldots$ & $\ldots$ & $\ldots$ & $\ldots$ \\
\hline A2 & $\ldots$ & $\ldots$ & $\ldots$ & $\ldots$ & $\ldots$ \\
\hline A3 & $\cdots$ & $\ldots$ & $\cdots$ & $\cdots$ & $\ldots$ \\
\hline$\sqrt{\sum_{i=1} x_{i j}^{2}}$ & $\cdots$ & $\cdots$ & $\cdots$ & $\cdots$ & $\cdots$ \\
\hline Optimization direction & $\mathrm{MIN}$ & MIN & MIN & MAX & MAX \\
\hline Integrated significance, \% & $\cdots$ & $\cdots$ & $\cdots$ & $\ldots$ & $\ldots$ \\
\hline Theoretical significance, \% & $\ldots$ & $\ldots$ & $\ldots$ & $\ldots$ & $\ldots$ \\
\hline
\end{tabular}

The criteria weighting factor results are presented in Table.

A multiple criteria decision analysis method was also applied to select the most rational option for the erection of the retaining wall. To select the most rational option for the erection of the retaining wall was created the initial Matrix B, which is presented in Table 5.

\section{Table 5}

View of initial Matrix B of alternative solutions 
Afterwards, Matrix B was normalized. The reason for matrix normalization is that the data in initial matrix $B$ are expressed in different units of measurement and thus are not possible to compare. Normalization of initial Matrix B produces non-dimensional values. Matrix B was normalized using (6) equation:

$$
x_{i j}=\frac{x_{i j}}{\sqrt{\sum_{i=1}^{j} x_{i j}{ }^{2}}}, i=1, m ; j=1, n \text {; }
$$

here: $x_{i j}-i$ - line and $j$ - column of Matrix.

Following the normalization of Matrix B, a weighted normalized Matrix B*of alternative solutions is created. To this end the normalized Matrix $B$ is multiplied by the vector of criteria weight using (7) equation:

$$
B^{*}=[B] \cdot[q],
$$

The ideal best condition $\mathrm{a}^{+}$(the best value) and the ideal worst condition $\mathrm{a}^{-}$(the worst value) are found. Distances between the real option $\mathrm{a}_{\mathrm{i}}$ and the ideal best condition $\mathrm{a}^{+}$, as well as between the real option $\mathrm{a}_{\mathrm{i}}$ and the ideal worst condition $\mathrm{a}^{-}$are computed using $(8,9)$ equations:

$$
\begin{aligned}
& {L^{+}}_{i}=\sum_{j=1}^{n}\left|f_{i j}-f_{j}^{+}\right|, \quad \mathrm{i}=1, \mathrm{~m} ; \mathrm{j}=1, \mathrm{n} ; \\
& L^{-}{ }_{i}=\sum_{j=1}^{n}\left|f_{i j}-f_{j}^{-}\right|, \quad \mathrm{i}=1, \mathrm{~m} ; \mathrm{j}=1, \mathrm{n} ;
\end{aligned}
$$

The relative proximity of compared options to the ideal option is found, i.e. criterion $K_{b i t}$ is calculated. Having the criterion $K_{\text {bit }}$ value calculated, the priority rank of compared options is made. In our case, the best option is the one that has the highest value of criterion $K_{\text {bit }}$ In the last stage the degree of utility $N_{i}$ of compared options is calculated using (10) equation:

$$
K_{b i t}=\frac{L_{i}^{-}}{L_{i}^{+}+L_{i}^{-}}, \mathrm{i}=1, \mathrm{~m} ; \mathrm{j}=1, \mathrm{n} \text {; }
$$

The most rational engineering option is the one with the highest value. Then the degree of utilityis calculated according to equation 11 to compare the value of the analysed option with the value of the ideal option.

$$
N_{1}=\frac{K_{b i t, 1}}{K_{b i t, \max }} \cdot 100 \%
$$

The rational engineering options are presented in Table.

Rational types of permanent retaining walls with ground anchors were calculatedusing the software GEO 5, taking into consideration different grounds and adjacent buildings. The summary of results leads to the conclusion that in terms of work complexity and costs, it is rational to install retaining walls in clay grounds. In clay grounds lower movement of structures occurs and there is no need to lower the ground water level. Smaller cross-section of the tendons is required to retain the ground load compared to sand grounds. The consumption of cement and water mortar is much higher in sandy grounds compared to the clay grounds. 
It can be assumed from the summary of survey results, which show the rational type of retaining wall with ground anchors selected by the evaluators according to the given conditions and evaluation criteria, that a pile wall is the rational solution for retaining walls with ground anchors erected next to existing buildings, whereas in all other cases the steel sheet pile is the most rational option. Adjacent buildings have a great influence on retaining wall installation, especially the buildings with shallow foundations, because the load borne by the foundation at the retaining wall is transferred to the structure. If the existing buildings have pile foundations, the load is usually transferred to deeper ground layers and has less influence on the retaining wall.

All chosen cases from 1 to 6 were distinguished after criteria weights were determined using the entropy technique. For example, one case is an existing building close to the retaining wall. In this case the most significant theoretical criteria were seasonality and installation time, and the most significant integrated criterion was the installation time. The other one case is the retaining wall without an existing building in the vicinity. In this case the most significant criterion, both theoretical and integrated, is the cost of machinery. The criteria weighting factor results are presented in Table 6.

\begin{tabular}{c|c|c|c|c|c|c}
\hline $\begin{array}{c}\text { Evaluation of criteria } \\
\text { weight }\end{array}$ & $\begin{array}{c}\mathrm{K} 1, \text { Labour } \\
\text { cost }\end{array}$ & $\begin{array}{c}\mathrm{K} 2 \text {, Machinery } \\
\text { cost }\end{array}$ & $\begin{array}{c}\mathrm{K} 3, \text { Material } \\
\text { cost }\end{array}$ & $\begin{array}{c}\mathrm{K} 4, \\
\text { Seasonality }\end{array}$ & $\begin{array}{c}\mathrm{K} 5 \text {, Installation } \\
\text { time }\end{array}$ \\
\hline \multicolumn{6}{c}{ Case 1 - Retaining walls with ground anchors in sandy soil with a high level of ground water } \\
\hline Theoretical & 0.1482 & 0.5612 & 0.0374 & 0.1991 & 0.0541 \\
\hline Integrated & 0.2281 & 0.5759 & 0.0384 & 0.1021 & 0.0556 \\
\hline
\end{tabular}

Case 2 - Ret. walls with ground anchors installed close to existing buildings in sandy soil with a high level of ground water

\begin{tabular}{c|l|l|l|l|l}
\hline Theoretical & 0.0672 & 0.2444 & 0.1069 & 0.2908 & 0.2908 \\
\hline Integrated & 0.1135 & 0.2752 & 0.1204 & .01637 & 0.3273 \\
\hline
\end{tabular}

Case 3 - Retaining walls with ground anchors in sandy soil (without ground water and a building in close proximity)

\begin{tabular}{c|l|l|l|l|l}
\hline Theoretical & 0.1914 & 0.7150 & 0.0196 & 0.0147 & 0.0593 \\
\hline Integrated & 0.2638 & 0.6570 & 0.0180 & 0.0068 & 0.0544 \\
\hline
\end{tabular}

Case 4 - Retaining walls with ground anchors in sandy soil (without water) close to existing buildings)

\begin{tabular}{c|l|l|l|l|l}
\hline Theoretical & 0.0511 & 0.2272 & 0.0210 & 0.3503 & 0.3503 \\
\hline Integrated & 0.0902 & 0.2671 & 0.0247 & 0.2060 & 0.4120 \\
\hline
\end{tabular}

Case 5 - Retaining walls with ground anchors in clay soil

\begin{tabular}{c|l|l|l|l|l}
\hline Theoretical & 0.1614 & 0.6028 & 0.1359 & 0.0500 & 0.0500 \\
\hline Integrated & 0.2293 & 0.5710 & 0.1287 & 0.0237 & 0.0473 \\
\hline
\end{tabular}

Case 6 - Retaining walls with ground anchors in clay soil close to existing building

\begin{tabular}{l|l|l|l|l|l}
\hline Theoretical & 0.0701 & 0.2617 & 0.0455 & 0.3114 & 0.3114 \\
\hline Integrated & 0.1195 & 0.2976 & 0.0518 & 0.1770 & 0.3541 \\
\hline
\end{tabular}

A multiple criteria analysis of three options of retaining walls with ground anchors installed in sandy ground with high ground water level and an existing building in close proximity revealed that the best solution is Option 2. This option is a pile wall. The maximum value of the degrees of utility (\%) was obtained in this case. Piles with the diameter of $\varnothing 450 \mathrm{~mm}$ and length $L=12 \mathrm{~m}$,

\section{Table 6}

Criteria priorities for each alternative solution using entropy technique 
reinforced with $8020 \mathrm{~mm}$ tendons along the entire length should be used for the retaining wall. Multiple criteria analysis of three options of retaining walls with ground anchors in clay ground shows that Option 1 is the best design solution. It means that Berlin Wall is the best retaining wall type for clay ground. HEB 220 type profiles with the length $L=8 \mathrm{~m}$ should be used for the erection of the retaining wall.

Fig. 3

Computation schemes of a retaining walls of the best rational solutions

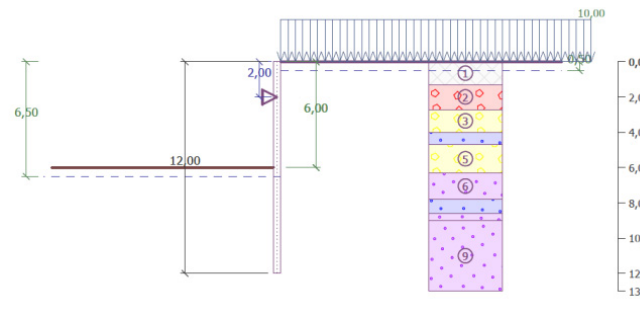

Computation scheme of Berlin wall (case 1)

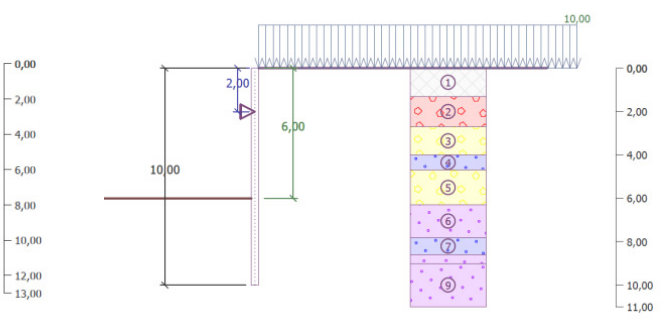

Computation scheme of Berlin wall (case 3)

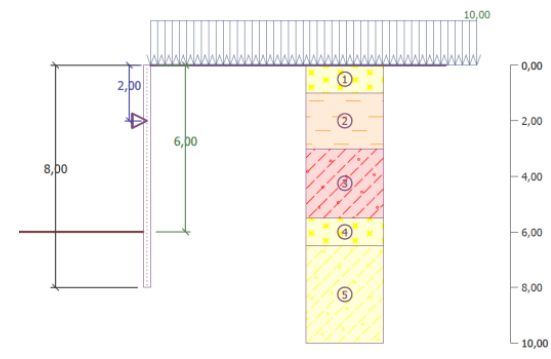

Computation scheme of Berlin wall (case 5)

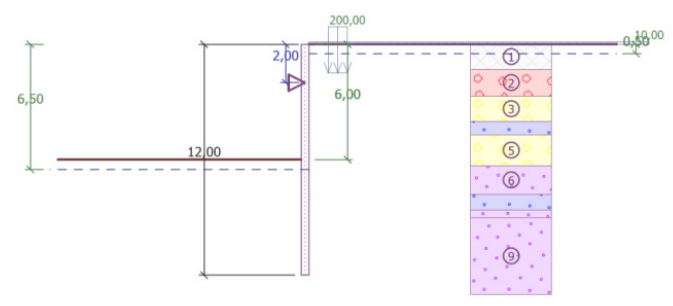

Computation scheme of pile wall (case 2)

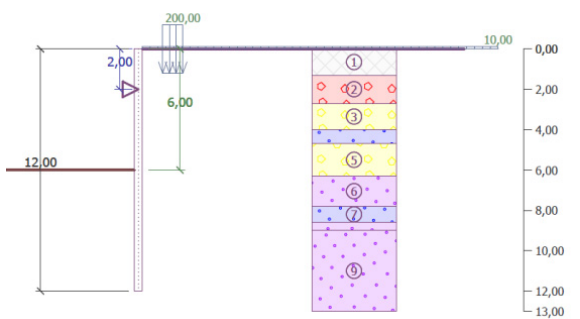

Computation scheme of pile wall (case 4)

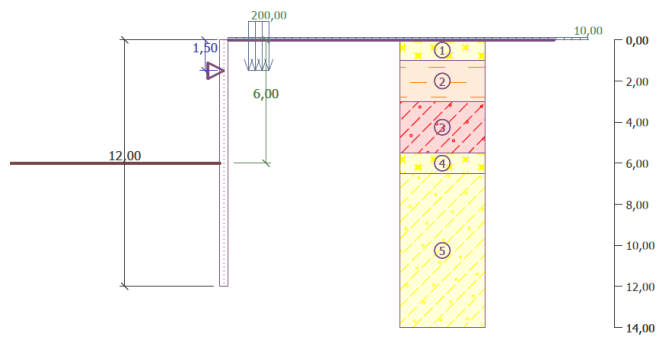

Computation scheme of pile wall (case 6) 
Fig. 3 illustrates the best rational solutions of retaining wall computation schemes. In Fig. 3 the computation scheme of sheet wall was not given because in all investigated cases (Table 6) this type of retaining wall was not a rational solution.

\begin{tabular}{|l|l|l|l}
\hline Alternatives & A1 & A2 & A3 \\
\hline
\end{tabular}

Case 1 - Retaining walls with ground anchors in sandy ground with a high level of ground water

Degree of utility options, \%

100.0

7.2

89.2

Case 2 - Ret. walls with ground anchors installed close to existing buildings in sandy ground with a high level of ground water

\begin{tabular}{r|c|c|c|}
\hline Degree of utility options, \% & 72.1 & 100.0 & \\
\hline Case 3 - Retaining walls with ground anchors in sandy ground (without ground \\
water and a building in close proximity)
\end{tabular}

Degree of utility options, \%

100.0

0.4

78.1

Case 4 - Retaining walls with ground anchors in sandy ground (without water) close to existing buildings)

\begin{tabular}{l|c|c|c}
\hline Degree of utility options, \% & 48.9 & 100.0 & 34.1 \\
\hline
\end{tabular}

Case 5 - Retaining walls with ground anchors in clay ground

\begin{tabular}{l|c|c|c}
\hline Degree of utility options, \% & 100.0 & 9.1 & 73.0 \\
\hline \multicolumn{2}{c}{ Case 6 - Retaining walls with ground anchors in clay ground close to existing building } \\
\hline Degree of utility options, \% & 68.7 & 100.0 & 52.0 \\
\hline
\end{tabular}

A multi-criteria evaluation by the method of efficiency value proved that Berlin wall is the most rational version of a retaining wall if it is installed with ground anchors in sandy soil with a high level of groundwater or without it and in clayey soil with no building in the vicinity. While installing it, the cost of human labour is 2 times, and the cost of mechanism work is even five times lower than the installation of a pile wall. However, a pile wall is the most rational version of a retaining wall in sandy soil with a high level of groundwater or without it and in clayey soil with a building nearby. Installation of a pile retaining wall needs 1.5 times less materials than a Berlin wall and it is the most cost-effective option from the point of view of duration.

1. In accordance with the provided conditions and criteria in the questionnaire, the results of the questionnaire from the enterprises experienced in installing retaining walls with ground anchors indicate that a pile wall is appropriate to install next to existing buildings while in other cases a Berlin wall should be constructed.

2. Evaluating criteria priorities by the method of entrophy it is clear when there is a building near a retaining wall the most significant theoretical criteria are seasonal prevalence and installation duration, the most important complex criterion is installation duration. Otherwise, when there is no building next to the retaining wall, both theoretical and complex creteria are the operating costs of the equipment.

3. The multi-criteria evaluation by the method of utility value found that a rational wall installation version is a pile wall when it is installed adjacent to existing buildings. The Berlin wall is the most rational version of retaining wall installation with no adjacent buildings

\section{Table 6}

Degree of utility for each alternative solution using entropy technique

\section{Conclusions}




\section{References}

AARSLEFF. http://www.aarsleff.com.pl/lt/pasilymas, [Interactive]. 2016.

ArcelorMittal Piling Handbook 8th edition, 2008, available at http://sheetpiling.arcelormittal.com/ uploads/files/ArcelorMittal\%20Piling\%20Handbook_rev08.pdf

Byfield M.P., Mawer R. W. Analysis of reduced modulus action in $U$-section steel sheet piles. Journal of constructional steel research, 2004; 60: 401-410. https://doi.org/10.1016/S0143-974X(03)00119-6

Day R.W. Geotechnical and foundation engineering. Design and construction. New York: McGraw Hill Professional, 1999, $750 \mathrm{p}$.

El-Nagar M.E. Enhancement of steel sheet-piling quay walls using grouted anchors. Journal of soil science and environmental management, 2010; 1(4): 69-76.

Gil-Martín L.M., Hernández-Montes E., Aschheim M. Optimization of piers for retaining walls. Structural and Multidisciplinary optimization, 2010; 41 (6): 979987.https://doi.org/10.1007/s00158-010-0481-2
Katkevičius L, Baublys R. Construction of waterways, quays and embankments. Kaunas: Ardiva. 2008. 77 p. (in Lithuanian).

Konstantakos D.C. Advantages and limitations of ultimate limit state design methods for braced excavations. Earth retention conference (ER), August 1-4, Bellevue, Washington, United States, 2010 818-820. https://doi.org/10.1061/41128(384)82

Kreišmantas A. Analysis of stress and deformation of steel sheet walls on tension forces of anchor 2016. 63 p. (in Lithuanian).

EN 1536:2000. Execution of special geotechnical work - Bored piles.

Merifield R.S., Lyamin A.V., Sloan S.W., Yu H.S. Three-dimensional lower bound solutions for stability of plate Anchors in clay. Journal of geotechnical and geoenvironmental engineering, 2003; 129(3): 243-253. https:// doi.org/10.1061/(ASCE)1090-0241(2003)129:3(243)

Van Baars S. Design of sheet pile installation by vibration. Geotechnical and geological engineering, 2004; 22(3): 391-400. https://doi.org/10.1023/B:GEGE.0000025047.17363.f8

\section{About the Authors}

MINDAUGAS ŽAGARINSKAS

Engineer

UAB "Projektana”

Main research area

Civil engineering.

Address

Chemijos str. 23D, LT-51331

Kaunas, Lithuania

Tel. +370 37300473

E-mail:

mindaugas.zagarinskas@

projektana.lt

\section{MINDAUGAS DAUKŠYS}

Dr.

Faculty of Civil Engineering and Architecture

\section{Main research area}

Civil engineering, construction technology.

\section{Address}

Studentu str. 48, LT-51367

Kaunas, Lithuania

Tel. +370 37300473

E-mail: mindaugas.dauksys@ktu.lt

\section{JŪRATÉ MOCKIENĖ}

\section{Master}

Faculty of Civil Engineering and Architecture

\section{Main research area}

Civil engineering.

Address

Studentu str. 48, LT-51367

Kaunas, Lithuania

Tel. +370 37300473

E-mail: jurate.mockiene@ktu.lt 